\title{
PENGARUH GAYA KEPEMIMPINAN DAN BUDAYA ORGANISASI TERHADAP KINERJA PEGAWAI PADA UPTD BALTEKKOMDIK DINAS PENDIDIKAN PROVINSI SUMATERA BARAT
}

\author{
Riko Junaidi, Febsri Susanti \\ Sekolah Tinggi Ilmu Eknomi "KBP” \\ febsrisusanti@akbpstie.ac.id
}

\begin{abstract}
This study aims to determine the influence of Leadership Style and Organizational Culture on Employee Performance at UPTD Baltekkomdik Education Office of West Sumatra Province. Data collection of this study through the distribution of questionnaires to 26 respondents using total sampling technique, where the entire sample population. Based on the result of research indicate that variable of Leadership Style T count equal to 7,951> T table 1,688 and level of significance T smaller than 0,05 (sig. 0,000 <0,05) hence Ha accepted. While the Organizational Culture variable $T$ count is $0.699<T$ table 1.688 and the significance level $T$ is greater than 0.05 (sig. 0,010>0,05) then $\mathrm{HO}$ is accepted. can be partially inferred leadership style has a significant influence on employee performance, while organizational culture partially no significant effect on employee performance. Keywords: Leadership Style, Organizational Culture and Performance
\end{abstract}

\section{PENDAHULUAN}

Menyonsong Abad 21 persaingan kerja semakin tinggi dan semakin kompleks sehingga setiap pegawai di tuntut untuk memperbaiki hal-hal yang terkait dalam setiap kinerja pegawai dan lebih responsive agar terus bertahan dan terus berkembang. Banyak hal yang mesti di benahi dan di perbaiki dari semua aspek khususnya pada sumber daya manusia. Aspek sumber daya manusia pada setiap pegawai harus di perhatikan agar sumber daya manusia yang ada selalu senantiasa terjaga, baik kesehatan, kompensasi ataupun kinerja yang kondusif dan menghasilkan produktivitas sesuai dengan visi yang disepakati bersama.

Kinerja sumber daya manusia atau pegawai dalam suatu kantor dapat di pengaruhi oleh berbagai faktor yang di antaranya gaya kepemimpinan dan budaya organisasi. Dimana gaya kepemimpinan dan budaya organisasi dapat mempengaruhi perilaku-perilaku pegawai dalam suatu instansi dinas.

Kinerja merupakan suatu fungsi kemampuan pekerja dalam menerima tujuan pekerjaan. Tingkat pencapaian tujuan dan interaksi antara tujuan dan kemampuan pekerja menurut Gorden dalam Nawawi (2006:63). Dengan definisi tersebut dapat di katakan bahwa pegawai memegang peranan penting dalam menjalankan segala aktivitas pegawai agar dapat tumbuh dan berkembang mempertahankan kelangsungan hidup instansi kedepannya.

Upaya-upaya dalam meningkatkan kinerja pegawai selain pengendalian internal 
gaya kepemimpinan juga perlu di perhatikan. Seorang pemimpin yang ideal harus memiliki gaya kepemimpinan yang baik sehingga dapat meningkatkan kinerja instansi dinas. Seorang pemimpin sangat perlu memperhatikan gaya kepemimpinan dalam proses mempengaruhi, mengarahkan kegiatan anggota kelompoknya serta mengordinasikan tujuan anggota dan tujuan organisasi agar keduanya dapat tercapai.

Gaya kepemimpinan yang baik adalah gaya kepemimpinan yang dapat memberikan motivasi kerja pada bawahannya. Widyatmini dan Hakim (2008:169) mengatakan seorang pemimpin harus melakukan berbagai keahlian, pengalaman, kepribadian dan motivasi setiap individu yang di pimpinnya. Gaya kepemimpinan yang efektif di butuhkan dalam suatu pegawai untuk dapat meningkatkan kinerja semua pegawai dalam mencapai tujuan yang telah di tetapkan pimpinan.

Selain gaya kepemimpinan, keberhasilan suatu organisasi atau pegawai dalam mencapai tujuannya dapat di pengaruhi juga oleh Budaya Organisasi. Di mana budaya organisasi merupakan pola, norma, keyakinan,dan nilai-nilai yang berlaku dalam suatu perusahaan, pola, norma, keyakinan dan nilai tersebut dapat mempengaruhi tindakan atau perilaku sumber daya manusia atau pegawai yang ada dalam suatu organisasi atau pegawai sehingga berimplikasi terhadap kinerja pegawai yang ada dalam suatu organisasi.

Menurut Schein (2012:12), budaya organisasi adalah pola dasar yang diterima oleh organisasi untuk bertindak dan memecahkan masalah, membentuk pegawai yang mampu beradaptasi dengan lingkungan dan mempersatukan anggota-anggota organisasi.

Pegawai yang telah memahami nilai-nilai dalam suatu organisasi akan menjadikan nilai tersebut sebagai kepribadian organisasi. Nilai dan keyakinan tersebut akan di wujudkan menjadi perilaku keseharian mereka dalam bekerja, sehingga akan menjadi kinerja individu dan masing - masing kinerja individu yang baik akan menimbulkan kinerja organisasi atau pegawai yang baik pula.

\section{TINJAUAN PUSTAKA}

Kepemimpinan

Kepemimpinan atau Leadership merupakan ilmu terapan dari ilmu-ilmu sosial, sebab prinsip-prinsip dan rumusan-rumusannya bermamfaat dalam meningkatkan kesejahteraan manusia. Sebagai langkah awal untuk mempelajari dan memahami segala sesuatu yang berkaitan dengan aspek-aspek kepemimpinan dan permasalahannya, perlu di pahami terlebih dahulu makna atau pengertian dari kepemimpinan melalui berbagai macam perspektif.

Arep \& Tanjung (2002:235) menerangkan bahwa "Kepemimpinan adalah kemampuan seseorang untuk menguasai atau mempengaruhi orang lain atau masyarakat yang saling berbeda-beda menuju kepada pencapaiaan tujuan tertentu ".

Robbins (2006:432) menyatakan kepemimpinan adalah kemampuan untuk mempengaruhi kelompok menuju pencapaian sasaran.

Kartono (2005:153) menyatakan kepemimpinan adalah kemampuan untuk memberikan pengaruh yang konstruktif kepada orang lain untuk melakukan suatu usaha kooperatif mencapai tujuan yang sudah di rencanakan.

Berdasarkan defenisi-defenisi di atas maka dapat disimpulkan bahwa 
kepemimpinan adalah kemampuan seseorang untuk mempengaruhi orang lain untuk mencapai tujuan yang ingin dicapai.

\section{Organisasi}

Dalam kehidupan masyarakat sehari hari tidak terlepas dari ikatan budaya yang di ciptakan. Ikatan budaya tercipta oleh masyarakat yang bersangkutan, baik dalam keluarga, organisasi, bisnis maupun bangsa. Budaya membedakan masyarakat satu dengan yang lain dalam cara berinteraksi dan bertindak menyelesaikan suatu pekerjaan. Budaya mengikat anggota kelompok masyarakat menjadi satu kesatuan pandangan yang menciptakan keseragaman berperilaku atau bertindak. Seiring dengan bergulirnya waktu, budaya pasti terbentuk dalam organisasi dan dapat pula di rasakan manfaatnya dalam memberi kontribusi bagi efektivitas organisasi secara keseluruhan.

Berikut ini di kemukakan beberapa pengertian budaya organisasi menurut para ahli:

Ivancevich (2006:44) mendefinisikan bahwa budaya organisasi adalah apa yang dipersepsikan pegawai dan cara persepsi itu menciptakan suatu pola.

Robbins (2002:247) mengatakan bahwa budaya organisasi merupakan suatu persepsi bersama yang di anut oleh anggota-anggota organisasi.

Menurut Schein (1992:12), budaya organisasi adalah pola dasar yang diterima oleh organisasi untuk bertindak dan memecahkan masalah, membentuk pegawai yang mampu beradaptasi dengan lingkungan dan mempersatukan anggota-anggota organisasi.

Untuk itu harus diajarkan kepada anggota termasuk anggota yang baru sebagai suatu cara yang benar dalam mengkaji, berpikir dan merasakan masalah yang dihadapi.

Menurut Peter. F Drucker dalam Tika (2006:4) budaya organisasi adalah pokok penyelesaian masalah-masalah eksternal dan internal yang pelaksanaanya di lakukan secara konsisten oleh suatu kelompok yang kemudian di wariskan kepada anggota-anggota baru sebagai cara yang tepat untuk memahami, memikirkan dan merasakan terhadap masalah-masalah yang terkait.

Berdasarkan definisi dapat di simpulkan bahwa budaya organisasi merupakan suatu prinsip dasar dari suatu organisasi. Hal ini meliputi berbagai nilai, keyakinan, norma, dan perilaku yang di anut oleh organisasi dan menjadi ciri khas dari organisasi tersebut.

\section{Kinerja}

Kinerja merupakan perilaku organisasi yang secara langsung berhubungan dengan produksi barang atau penyampaian jasa. Informasi tentang kinerja organisasi merupakan suatu hal yang sangat penting di gunakan untuk mengevaluasi apakah proses kerja yang dilakukan organisasi selama ini sudah sejalan dengan tujuan yang di harapkan atau belum. Akan tetapi dalam kenyataannya banyak organisasi yang justru kurang atau bahkan tidak jarang ada yang mempunyai informasi tentang kinerja dalam organisasinya. Kinerja sebagai hasil-hasil fungsi pekerjaan / atau kegiatan seseorang atau kelompok dalam suatu organisasi yang di pengaruhi oleh berbagai faktor untuk mencapai tujuan organisasi dalam periode waktu tertentu (Tika, 2006:26). 


\section{Hipotesis}

Hipotesis pada dasarnya merupakan dugaan atau jawaban sementara permasalahan yang diteliti (Mangusdi dan Salim 2012.72), maka hipotesis yang diajukan dalam penelitian ini sebagai berikut:

Jawaban sementara yang dapat diambil dari penelitian ini adalah :

1. Gaya kepemimpinan berpengaruh parsial terhadap kinerja pegawai UPTD. Baltekkomdik Dinas Pendidikan Provinsi Sumatera Barat.

2. Budaya organisasi berpengaruh parsial terhadap kinerja pegawai UPTD. Baltekkomdik Dinas Pendidikan Provinsi Sumatera Barat.

\section{METODE PENELITIAN}

\section{Jenis Penelitian}

Sebelum melaksanakan penelitian di lapangan, perlu disusun metode penelitian yang tepat untuk digunakan dalam menyusun penelitian dalam studi ini, maka pelakasanaan penelitian yang akan peneliti mengunakan metode deskriptif dengan pendekatan kuantitatif dan kualitatif.

Pendekatan dekriptif kuantitatif didapatkan dari proses pengolahan data respoden melalui penyebaran atau pengisian kuisioner dan pendekatan deskriptif kualitatif, dimana data kuantitatif yang telah diolah akan dari interprestasikan sesuai dengan hasil perolehan data yang sesuai dengan keadaan di lapangan yang nantinya akan penulis paparkan pada pembahasan dalam penelitian ini.

\section{Objek Penelitian}

Adapun yang menjadi responden dalam penelitian ini adalah seluruh pegawai pada UPTD Baltekkomdik Dinas Pendidikan Provinsi Sumatera Barat, dimana penelitian ini akan dapat memberikan gambaran secara umum mengenai pengaruh gaya kepemimpinan dan budaya organisasi terhadap kinerja pegawai Pada UPTD Baltekkomdik Dinas Pendidikan Provinsi Sumatera Barat.

\section{Populasi dan Sampel}

\section{Populasi}

Menurut Arikunto ( 2013:173) populasi adalah keseluruhan dari subjek penelitian. Jadi yang dimaksud dengan pupulasi individu yang memiliki sifat yang sama walaupun prosentase kesamaan itu sedikit, atau dengan kata lain seluruh individu yang akan dijadikan objek penelitian. Sedangkan Sugiyono (2013:117) populasi adalah generalisasi yang terdiri atas objek/subjek yang mempunyai kulitas dan karakteristik tertentu yang ditetapkan oleh peneliti untuk dipelajari dan kemudian ditarik kesimpulan.

Dalam penelitian yang akan penulis lakukan, populasinya adalah semua pegawai yang bekerja di UPTD Baltekkomdik Dinas Pendidikan Provinsi Sumatera Barat yang berjumlah 26 orang.

\section{Sampel}

Arikunto (2013:174 ) berpendapat bahwa sampel adalah sebagian atau wakil populasi yang diteliti. Sedangkan menurut sugiyono (2013: 118) sampel adalah bagian dari jumlah dan karakteristik yang dimiliki oleh populasi tersebut. Berdasarkan jumlah populasi sebanyak 26 orang, maka besar sampel yang akan diambil pada penelitian ini berdasarkan pendapat Danim (2007) menjelaskan: Jika 
populasinya kurang dari 100, Iebih baik semua populasinya dijadikan sampel, selanjutnya jika populasinya lebih dari 100 maka sampelnya minimal 10-25\%. Berdasarkan pendapat di atas, maka populasi dari penelitian ini kurang dari 100, sehingga penulis menjadikan semua jumlah populasi menjadi sampel yaitu 26 orang.

\section{Jenis Data Penelitian}

Data yang penulis gunakan dalam penelitian yang akan penulis lakukan adalah dalam bentuk:

1. Data Primer

Yaitu merupakan data yang diperoleh dalam bentuk baku dan masih membutuhkan pengelolaan lebih lanjut yang nantinya berupa kuesioner.

2. Data Sekunder

Yaitu data yang diperoleh melalui studi dokumentasi serta catatan yang relevan dengan penelitian berupa data penilaian kinerja dan data penyelesaian program kerja pada UPTD Baltekkomdik Dinas Pendidikan Provinsi Sumatera Barat.

\section{Teknik Pengumpulan Data}

Dalam penelitian yang akan penulis lakukan ini, teknik-teknik pengumpulan data yang akan penulis gunakan yaitu melalui cara-cara sebagai berikut:

1. Komunikasi Langsung

Dengan teknik ini penulis melakukan wawancara dengan pegawai pada UPTD Baltekkomdik Dinas Pendidikan Provinsi Sumatera Barat, ataupun pihak terkait.

2. Studi Dokumenter

Yaitu dengan mencatat data yang telah tersedia yang berhubungan dengan permasalahan penelitian yang telah dilaksanakan.

\section{HASIL PENELITIAN DAN PEMBAHASAN}

\section{Hasil Uji Instrumen}

\section{Hasil Uji Validitas}

Menurut Gfyozali, (2007:49) penguji validitas tiap butir digunakan analisa item, yaitu mengkorelasikan skor tiap butir dengan skor total yang merupakan jumlah tiap butir (corrected item total correlation) dan nilainya dapat dilihat pada hasil pengelohan menggunakan program SPSS pada tabel item- total statistic di kolom corrected item total correlation. Validnya sebuah ditentukan dari nilai koefisien kolerasl yang dihasilkan besar dari 0,30 dan dapat digunakan untuk selanjutnya.

Hasil uji validitas ditunjukan pada Tabel di bawah ini 
Tabel 1.

Hasil Uji Validitas

\begin{tabular}{|c|c|c|c|c|}
\hline Variabel & Indikator & Korelasi & Minimal Korelasi & Keterangan \\
\hline Gaya & 1 & 0,386 & 0.30 & Valid \\
Kepemimpinan & 2 & 0.550 & 0.30 & Valid \\
& 3 & 0.350 & 0.30 & Valid \\
& 4 & 0.632 & 0.30 & Valid \\
& 5 & 0,495 & 0.30 & Valid \\
\hline Budaya & 1 & 0,802 & 0.30 & Valid \\
Organisasi & 2 & 0,807 & 0.30 & Valid \\
& 3 & 0,415 & 0.30 & Valid \\
& 4 & 0,474 & 0.30 & Valid \\
& 5 & 0,466 & 0.30 & Valid \\
\hline Kinerja Pegawai & 1 & 0,397 & 0.30 & Valid \\
& 2 & 0,471 & 0.30 & Valid \\
& 3 & 0,538 & 0.30 & Valid \\
& 4 & 0,703 & 0.30 & Valid \\
\hline
\end{tabular}

Sumber : Data hasil olahan kuisioner, 2018

Berdasarkan pada tabel di atas dapat di ketahui bahwa nilai yang di peroleh untuk 5 item pernyataan variabel kinerja memiliki nilai korelasi lebih besar dari 0,30 sehingga dapat di simpulkan bahwa keseluruhan pernyataan dalam variabel ini telah valid.

\section{Uji Reabilitas}

Menurut Ghozali (2007:45), reliabilitas sebenarnya adalah alat untuk mengukur suatu kuesioner yang merupakan indikator dari suatu variabel atau konstruk. Secara umum uji reliabilitas didefenisikan sebagai rangkaian uji lanjutan untuk menilai kehandalan dari item-item pertanyaan yang valid yang dilihat dari nilai cronbach alpha yang dihasilkan $>0,60$. Berdasarkan uji reliabilitas yang dilakukan pada variabel gaya kepemimpinan (X1), budaya organisasi (X2) dan kinerja pegawai (Y) dapat dilihat pada Tabel dibawah ini:

Tabel 2

Uji Realibilitas

\begin{tabular}{|l|c|c|c|}
\hline \multicolumn{1}{|c|}{ Variabel } & $\begin{array}{c}\text { Cronbach's } \\
\text { Alpha }\end{array}$ & $\begin{array}{c}\text { Standar } \\
\text { Reabilitas }\end{array}$ & Keterangan \\
\hline Kedisiplinan(X1) & 0,717 & 0,60 & Reliabel \\
\hline Kompensasi(X2) & 0,804 & 0,60 & Reliabel \\
\hline Kinerja(Y) & 0,749 & 0,60 & Reliabel \\
\hline
\end{tabular}

Sumber : Data hasil olahan kuisioner, 2018 
Dari Tabel di atas dapat diambil kesimpulan bahwa dari uji reliabilitas yang dihasilkan nilai Cronbach's Alpha untuk variabel budaya organisasi, gaya kepemimpinan dan kinerja pegawai dinyatakan reliabel karena nilai Cronbach's Alpha yang dihasilkan lebih dari 0,60 sehingga item-item pernyataan termasuk dalam kategori handal dan variabel tersebut dapat digunakan sebagai alat ukur dalam penelitian ini

\section{Uji Regresi Linear Berganda}

\section{Tabel 3}

Hasil Uji Regresi Linear Berganda

\begin{tabular}{|c|c|c|c|c|c|c|}
\hline \multirow{2}{*}{\multicolumn{2}{|c|}{ Model }} & \multicolumn{2}{|c|}{ Unstandardized Coefficients } & \multirow{2}{*}{$\begin{array}{l}\text { Standardized } \\
\text { Coefficients } \\
\text { Beta }\end{array}$} & \multirow[t]{2}{*}{$\mathrm{t}$} & \multirow[t]{2}{*}{ Sig. } \\
\hline & & B & Std. Error & & & \\
\hline \multirow{5}{*}{1} & (Constant) & ,355 & 1,433 & & ,248 & ,807 \\
\hline & Gaya & & & & & \\
\hline & Kepemimpin & ,932 & ,117 & ,888 & 7,951 & ,000 \\
\hline & Budava & & & & & \\
\hline & $\begin{array}{l}\text { Budaya } \\
\text { Organisasi }\end{array}$ & 067 & 101 & 075 & 669 &, 510 \\
\hline
\end{tabular}

Sumber: Data primer yang diolah, 2018

Berdasarkan analisis data dengan menggunakan program SPSS 20 for windows, maka diperoleh hasil persamaan regresi sebagai berikut:

$\mathrm{Y}=355+0,932 \mathrm{X} 1+0,067 \mathrm{X}_{2}+0,05$

Persamaan regresi di atas memperlihatkan hubungan antara variabel independen dengan variabel dependen seeara parsial, dari persamaan tersebut dapat diambil kesimpulan bahwa

1) Nilai constanta adalah $=355$ artinya jika tidak terjadi perubahan variabel gaya kepemimpinan dan budaya organisasi (nilai X1 dan X2 adalah 0) maka kinerja pegawai UPTD Baltekkomdik Dinas Pendidikan Provinsi Sumatera Barat tetap sebesar 355 satuan.

2) Nilai koefisien regresi budaya organisasi adalah $=0,932$ artinya jika variabel gaya kepemimpinan (X1) meningkat sebesar 1 (satuan) dengan asumsi variabel budaya organisasi (X2) dan konstanta (a) adalah 0 (nol), maka kinerja pegawai UPTD Baltekkomdik Dinas Pendidikan Provinsi Sumatera Barat meningkat sebesar 0,932 satuan.

3) Nilai koefisien regresi gaya kepemimpinan adalah $=0,0,67$ artinya jika variabel budaya organisasi (X2) meningkat sebesar 1 (satuan) dengan asumsi variabel gaya kepemimpinan (X1) dan kostanta (a) adalah 0 (nol), maka kinerja pegawai UPTD Baltekkomdik Dinas Pendidikan Provinsi Sumatera Barat meningkat sebesar 0,067 satuan.

\section{Uji Hipotes is}

\section{Uji Simultan ( Uji F)}

Uji F digunakan untuk mengetahui pengaruh semua variabel bebas seeara bersama-sama terhadap nilai variabel terikat. Pengujian ini dilakukan dengan membandingkan nilai Fhitung dengan F tabel. Jika Fhitung > F tabel, maka Ho 
ditolak dan Ha diterima. Artinya variabel bebas secara bersama-sama mempunyai pengaruh terhadap variabel terikat. Dan jika Fhitung < F tabel maka variabel bebas secara bersama-sama tidak mempunyai pengaruh terhadap variabel terikat. $\mathrm{F}$ tabel dicari dari tingkat kepercayaan (a) dan derajat kebebasan (k, n-k-1). Pengujian ini akan dilakukan dengan menguji $\mathrm{F}$ pada tingkat kepercayaan 95\% (a - 0,05) dan derajat kebebasan tertentu, sehingga dengan penguji uji $\mathrm{F}$ ini akan diketahui hubungan variabel independent $(\mathrm{X})$ dengan variabel dependent $(\mathrm{Y})$. Berdasarkan uji $\mathrm{F}$ yang dilakukan dapat dilihat pada label 4 dibawah ini:

\section{Tabel 4}

Hasil Uji F ANOVA ${ }^{b}$

ANOVA ${ }^{\mathrm{a}}$

\begin{tabular}{|c|c|c|c|c|c|c|}
\hline \multicolumn{2}{|c|}{ Model } & $\begin{array}{l}\text { Sum of } \\
\text { Squares }\end{array}$ & Df & $\begin{array}{l}\text { Mean } \\
\text { Square }\end{array}$ & $\mathrm{F}$ & Sig. \\
\hline \multirow{3}{*}{1} & Regression & 143,542 & 2 & 71,771 & 104,195 &, $000^{\mathrm{b}}$ \\
\hline & Residual & 15,843 & 23 & ,689 & & \\
\hline & Total & 159,385 & 25 & & & \\
\hline
\end{tabular}

Sumber : Data primer yang diolah, 2018

Berdasarkan hasil pengujian pada Tabel 4 di atas dapat dilihat pada nilai Fhitung sebesar 104,195 dengan nilai $\mathrm{F}$ tabel df2 = k-1 $(3-1=2)$, dfl = h-k (39-3= 36) adalah 3.26 sehingga nilai Fhitung 12,041 > F tabel 3.26, dan tingkat signifikan $0,000<0,05$ maka Ho ditolak dan H3 diterima, dapat disimpulkan bahwa variabel gaya kepemimpinan (X1) dan budaya organisasi (X2) secara bersamaan berpengaruh signifikan terhadap kinerja pegawai UPTD Baltekkomdik Dinas Pendidikan Provinsi Sumatera Barat.

\section{Uji Parsial (Uji t)}

Koeefisien regresi bertujuan untuk mengetahui apakah variabel bebas yang terhadap dalam persamaan secara individu berpengaruh terhadap nilai variabel terikat. Caranya adalah dengan melakukan pengujian hipotesis terhadap koefisien regresi semua dari hasil hipotesis ini, pada tingkat kepercayaan dan derajat kebebasan tertentu akan diperoleh hasil thitung dan ttabel sehingga dapat disimpulkan pengaruh antara variabel independent dengan dependent. Berdasarkan uji $\mathrm{t}$ yang dilakukan dapat dilihat pada Tabel 5 di bawah ini;

Berdasarkan tabel uji parsial di bawah dapat diketahui bahwa variabel kedisiplinan $\mathrm{T}$ hitung sebesar 6,815> $\mathrm{T}$ tabel 2,009 dan tingkat signifikansi $\mathrm{T}$ lebih kecil dari 0,05 (sig. $0,000<0,05)$ maka $\mathrm{H}_{\mathrm{a}}$ di terima. Sedangkan variabel kompensasi $\mathrm{T}$ hitung sebesar 1,892 < T tabel 2,009 dan tingkat signifikansi $\mathrm{T}$ lebih besar dari 0,05 (sig. $0,064>0,05)$ maka $\mathrm{H}_{0}$ diterima. dapat di simpulkan secara parsial kedisiplinan mempunyai pengaruh yang signifikan terhadap kinerja karyawan, sedangkan kompensasi secara parsial tidak berpengaruh signifikan terhadap kinerja karyawan. 


\section{Tabel 5}

Hasil Uji t

\section{Coefficients $^{\text {a }}$}

\begin{tabular}{|c|c|c|c|c|c|c|}
\hline \multirow{2}{*}{\multicolumn{2}{|c|}{ Model }} & \multicolumn{2}{|c|}{$\begin{array}{c}\text { Unstandardized } \\
\text { Coefficients }\end{array}$} & $\begin{array}{c}\text { Standardized } \\
\text { Coefficients }\end{array}$ & \multirow[t]{2}{*}{$\mathrm{t}$} & \multirow[t]{2}{*}{ Sig. } \\
\hline & & $\mathrm{B}$ & Std. Error & Beta & & \\
\hline \multirow{3}{*}{1} & (Constant) &, 355 & 1,433 & & ,248 & ,807 \\
\hline & $\begin{array}{l}\text { Gaya } \\
\text { Kepemimpinan }\end{array}$ & ,932 &, 117 &, 888 & 7,951 & ,000 \\
\hline & Budaya Organisasi & 067 &, 101 & 075 & ,669 & ,510 \\
\hline
\end{tabular}

Sumber : Data primer yang diolah, 2018

Berdasarkan hasil yang yang dilakukan pada tabel di atas dapat diketahui bahwa apabila nilai thitung $>$ ttabel dan nilai signifikan $<0,05$, maka dapat dikatakan bahwa variabel bebas tersebut berpengaruh signifikan secara individu terhadap variabel terikat dan apabila nilai thitung < ttabel dan nilai signifikan >0,05, maka variabel bebas tidak berpengaruh terhadap variabel terikat. 


\section{Uji Koefisien Determinasi (R2)}

Yaitu digunakan untuk mengetahui prosentase pengaruh semua variabel bebas terhadap nilai variabel terikat. Besarnya koefisien determinasi dari 0 sampai dengan 1, semakin rnendekati 0 besarnya koefisien determinasi suatu persamaan regresi, maka semakin kecil pengaruh sernua variabel bebas terhadap nilai variabel terikat.

\section{Tabel 6}

Hasil Uji Koefisien Determinasi Model Summary

\begin{tabular}{|c|c|c|c|c|c|c|c|c|c|}
\hline \multirow{2}{*}{ Model } & \multirow{2}{*}{$\mathbf{R}$} & \multirow{2}{*}{$\begin{array}{c}\mathbf{R} \\
\text { Square }\end{array}$} & $\begin{array}{c}\text { Adjusted } \\
\text { R Square }\end{array}$ & $\begin{array}{c}\text { Std. Error } \\
\text { of the } \\
\text { Estimate }\end{array}$ & $\begin{array}{c}\text { R Square } \\
\text { Change }\end{array}$ & $\begin{array}{c}\text { F } \\
\text { Change }\end{array}$ & df1 & df2 & $\begin{array}{c}\text { Sig.F } \\
\text { Change }\end{array}$ \\
\hline 1 & $0,949^{\mathrm{a}}$ & 0,901 & 0,892 & 8,2995 & 0,901 & 104,195 & 2 & 26 & 0,000 \\
\hline
\end{tabular}

Sumber: Data primer yang diolah, 2018

Berdasarkan Tabel dapat diketahui bahwa nilai koefisien determinasi terdapat pada nilai Adjusted R Square dengan sebesar 0,901. Hal ini berarti besar pengaruh variabel bebas terhadap variabel terikat adalah sebesar $90,1 \%$ sisanya $0,9 \%$ dijelaskan oleh variabel lain yang tidak dibahas dalam penelitian ini.

\section{Pembahasan Hasil Penelitian}

Berdasarkan analisa data mengenai pengaruh variabel gaya kepemimpinan (X1) dan variabel budaya organisasi (X2) serta secara individu dan secara bersamaan terhadap kinerja pegawai UPTD Baltekkomdik Dinas Pendidikan Provinsi Sumatera Barat, maka pembahasan hasilnya adalah sebagai berikut:

\section{1) Pengaruh Variabel Gaya Kepemimpinan Terhadap Kinerja Pegawai.}

Berdasarkan hasil penelitian yang dilakukan pada variabel gaya kepemimpinan ditemukan nilai thitung $>t_{\text {tabel }}(7,951>1,688)$, sedangkan nilai signifikan 0,000 , Artinya variabel gaya kepemimpinan berpengaruh terhadap kinerja pegawai. Berdasarkan hasil tersebut dapat disimpulkan bahwa kinerja pegawai UPTD Baltekkomdik Dinas Pendidikan Provinsi Sumatera Barat dapat dipengaruhi oleh faktor internal gaya kepemimpinan dan external gaya kepemimpinan. Hal ini disebabkan karena promosi jabatan yang diberikan kepada pegawai telah sesuai dengan ketentuan yang berlaku, sehingga promosi jabatan yang terjadi pada pegawai merupakan salah satu keberuntungan, bukan berdasarkan prestasi kerja pegawai, tetapi berdasarkan pendekatan antara pimpinan. Dengan terjadinya pemasalahan tersebut maka nantinya akan memberikan dampak yang positif terhadap kinerja pegawai, karena pegawai termotivasi untuk bekerja lebih baik lagi. Dalam rangka meningkatkan kinerja pegawai seharusnya pimpinan memberikan promosi jabatan berdasarkan prestasi kerja pada pegawai agar pegawai tersebut memiliki semangat yang tinggi untuk bekerja ke arah yang lebih baik.

Penelitian yang mendukung hasil penelitian adalah Falikhatun dalam Abdullah (2006:19) menyatakan bahwa kinerja juga dipengaruhi oleh tipe personalitas individu, yaitu individu dengan internal gaya kepemimpinanl lebih banyak berorientasi pada tugas yang dihadapinya, sehingga akan meningkatkan kinerjanya. 
Dibandingkan dengan individu dengan external gaya kepemimpinan, individu yang mempunyai Internal gaya kepemimpinan menunjukkan motivasi yang lebih besar, menyukai hal-hal yang bersifat kompetitif, suka bekerja keras, merasa dikejar waktu dan ingin selalu berusaha lebih baik dari pada kondisi sebelunuiya, sehingga mengarah pada pencapaian prestasi yang lebih tinggi.

Penelitian relevan atau sama dengan penelitian Abdulloh (2006) yang berjudul pengaruh budaya organisasi, gaya kepemimpinan dan kepuasan kerja terhadap kinerja pegawai pada kantor pelayanan pajak semarang barat. Berdasarkan penelitian tersebut didapatkan bahwa terdapat pengaruh positif dan signifikan antara gaya kepemimpinan terhadap kinerja pegawai. Hal berarti bahwa semakin tinggi gaya kepemimpinan ternyata dapat mendorong peningkatan kinerja pegawai pada Kantor Pelayanan Pajak Semarang Barat. Keadaan ini dikarenakan pegawai dapat memberdayakan gaya kepemimpinannya. baik internal maupun eksternal, sehingga tercipta kondisi kerja yang kompetitif dan berupaya untuk selalu mampu menghadapi permasalahan yang dihadapi dalam menyelesaikan pekerjaanya menjadi lebih baik, dalam mewujudkan kualitas, kuantitas, ketepatan dan kemandirian kinerjanya. Terdapat pengaruh positif dan signifikan antara budaya organisasi terhadap kinerja pegawai. Keadaan ini disebabkan oleh setiap pegawai yang mempunyai nilai, keyakinan dan perilaku yang sesuai dengan budaya kantor. Budaya organisasi yang kuat akan memicu pegawai untuk berpikir, berperilaku dan bersikap sesuai dengan nilai-nilai organisasi yang meliputi profesionalisme, percaya pada rekan, keteraturan dan integrasi, sehingga kesesuain ini dapat mendorong pegawai untuk meningkatkan kinerjanya menjadi lebih baik, dalam mewujudkan kualitas, kuantitas, ketepatan dan kemandirian kinerjanya.

\section{2) Pengaruh Variabel Budaya Organisasi Terhadap Kinerja Pegawai.}

Berdasarkan penelitian yang telah dilakukan pada variabel budaya kerja ditemukan nilai thitung > ttabel $(0,669<1,688)$, sedangkan nilai signifikan 0,510 , artinya tidak terdapat pengaruh yang signifikan antara variabel budaya kerja dengan kinerja pegawai. Berdasarkan hasil penelitian tersebut dapat disimpulkan bahwa kinerja pegawai UPTD Baltekkomdik Dinas Pendidikan Provinsi Sumatera Barat disebabkan oleh beberapa faktor seperti perhatian kerincian, orientasi hasil, orientasi orang, orientasi tim dan keagresifan. Sehingga pegawai dapat melaksanakan tanggungjawab yang diberikan kepadanya dengan baik baik, serta pegawai merasa senang dengan pekerjaan yang diberikan kepadanya karena pekerjaan tersebut telah sesuai dengan kemampuan yang dimiliki. Dengan adanya kemampuan yang dimiliki pegawai terhadap pekerjaan tersebut maka pegawai dapat bekerja dengan baik sehingga dapat membantu dalam pencapaian tujuan organisasi.

Teori yang mendukung hasil penelitian ini adalah Deal dan Kennedy (2010) menggambarkan bagaimana yang kuat mampu membantu pegawai mengerjakan tugasnya dengan lebih baik sehingga pegawai yang terlatih dalam budaya kerja akan mampu memecahkan permasalahan dengan bantuan keahlian atau keterampilan yang dimiliki, dengan kata lain budaya organisasi mempengaruhi keahlian atau seseorang dalam usaha meningkatkan kinerjanya.

\section{Kesimpulan}

Berdasarkan hasil penelitian dan pembahasan, maka dapat ditarik 
kesimpulan sebagai berikut :

1. Terdapat pengaruh positif dan signifikan gaya kepemimpinan terhadap kinerja pegawai pada UPTD Baltekkomdik Dinas Pendidikan Provinsi Sumatera Barat secara parsial.

2. Terdapat pengaruh positif dan signifikan budaya organisasi terhadap kinerja pegawai pada UPTD Baltekkomdik Dinas Pendidikan Provinsi Sumatera Barat Provinsi secara parsial.

\section{Saran}

Adapun saran diberikan adalah:

1. Karena semua variabel yang diteliti dalam penelitian ini menunjukkan pengaruh yang positif dan signifikan maka diharapkan bagi pimpinan instansi dinas UPTD Baltekkomdik untuk membuat kebijakan pegawai yang bisa mempertahankan indicator - indikator dari kepemimpinan dan budaya organisasi yang ada sekarang dan diharapkan di masa mendatang lebih ditingkatkan lagi dalam upaya meningkatkan kinerja instansi dinasnya agar lebih produktif lagi.

2. Diharapkan bagi peneliti berikutnya agar kiranya menambah variabel selain kepemimpinan dan budaya organisasi agar lebih memahami variabelvariabel yang mempengaruhi kinerja instansi dinas, antara lain kemampuan kerja, komunikasi, komitmen, semangat kerja, karakteristik pekerjaan dan lainlain.

3. Diharapkan perusahaan dapat menerapkan gaya kepemimpinan kepada pegawai, karena dengan adanya sikap yang baik pada diri pegawai, maka kinerja menjadi meningkat sehingga tujuan instansi dapat tercapai dengan baik.

\section{DAFTAR PUSTAKA}

Anggy, henly dkk. (2016). pengaruh budaya organisasi,disiplin kerja, dan lingkungan kerja terhadap kinerja karyawan pada PT PLN(Persero)Kantor Wilayah Suluttenggo.

Arfindy, parerung dkk. (2014). Disiplin, Kompensasi dan Pengembangan Karir Pengaruhnya Terhadap Kinerja Pegawai Pada Badan Lingkungan Hidup Provinsi Sulawesi Utara, 2(4).

Arikunto, S. (2002). Prosedur Penelitian Suatu Pendekatan Praktek, PT. Rineka Cipta, Jakarta.

Elizabeth, satriowati dkk. (2016). Pengaruh Gaya Kepemimpinan Transformasional, Kompensasi Dan Komunikasi Terhadap Kinerja Karyawan Dengan Kepuasan Kerja Sebagai Variabel Mediasi Pada Laundry Elephant King.

fudin, zainal abidin. (2013). Pengaruh Disiplin Terhadap Kinerja Karyawan Pada PT. Rekatama Putra Gegana Bandung. 
Ghozali, I. (2011). Aplikasi Analisis Multivariate dengan Program IBM SPSS 20 (6th ed.). Semarang: Universitas Diponegoro.

Hamlan, D. (2015). Pengaruh kompetensi, disiplin dan kompensasi terhadap kinerja pegawai badan pemberdayaan perempuan dan keluarga berencana daerah provinsi sulawesi tengah, 84-94.

Hasibuan S, P, M. (2012). Manajemen Sumber Daya Manusia. Edisi Revisi. PT Bumi Aksara. Jakarta.

Letjes. (2000). Jaminan sosial tenaga kerja. Jakarat: Erlangga.

Marlius, D. (2017). Keputusan Pembelian Berdasarkan Faktor Psikologis Dan Bauran Pemasaran Pada PT. Intercom Mobilindo Padang. Jurnal Pundi. Volume 1. No. 1. Hal. 57-66. https $/ /$ doi.org/10.31575/jp.v1i1.9

Minarsih, M. M. (2015). Pengaruh Kompensasi , Motivasi Kerja, Lingkungan kerja dan disiplin terhadap Kinerja Karyawan pada CV Koperasi Puri Kencana Taxi Semarang, 1-23.

Mustika Utami, F. (2014). Pengaruh Kompensasi dan di Siplin Kerja Terhadap Kinerja karyawan, 14.

Rivai. (2004). Manajemen Sumber Daya Manusia Untuk Perusahaan, Jakarta: PT. Rajagrafindo Persada. Jakarta: Murai Kencana.

Sastrohadiwiroyo. (2005). kedisiplinan kerja. bandung: alfabeta andy.

Simamora. (2004). Manajemen Sumber Daya Manusia Edisi III. Jakarta : STIE YKPN Sperling, 2007. "Psychology: Made Simple”, London, The Publisher W. H. Allen \& Co. Ltd. Supranto, 2009. Statistik Teori dan Aplikasi, Edisi ketujuh Jilid 2. Jakarta: Penerbit Erlangga.

Suciati, Sihombing \& Kennedy, 2016. (2000). Management Journal. Princeton, NJ, 9220(1), 63-79.

Sugiyono. (2015). Metode Penelitian dan Pengembangan, Penerbit Alfabeta Bandung. Yogyakarta. 